\title{
INNOVATIVE CONVERGED SERVICE AND ITS ADOPTION, USE AND DIFFUSION: A HOLISTIC APPROACH TO DIFFUSION OF INNOVATIONS, COMBINING ADOPTION-DIFFUSION AND USE-DIFFUSION PARADIGMS
}

\author{
Kazuyuki Motohashi ${ }^{1}$, Deog-Ro Lee ${ }^{2}$, Yeong-Wha Sawng ${ }^{3}$, Seung-Ho Kim ${ }^{4}$ \\ ${ }^{1}$ Department of Technology Management for Innovation, University of Tokyo, Japan \\ ${ }^{2}$ School of Business Management, Seowon University, Korea \\ 3218 Gajeong-ro, Yuseong-gu, Technoloy Foresight Research Team, ETRI 305-700, Korea \\ ${ }^{4}$ School of Health Service Management at Kyungwoon University, Korea \\ E-mails:1'motohashi@tmi.t.u-tokyo.ac.jp; 2 drlee@seowon.ac.kr; \\ 3ywsawng@gmail.com (correspondingauthor); ${ }^{3}$ ksuri@naverl.com
}

Received 01 February 2011; accepted 28 April 2011

\begin{abstract}
This study takes a holistic approach to understanding the diffusion of IPTV services by combining the adoption-diffusion model and the use-diffusion model of innovation. IPTV service, a leading converged application that couples media content with telecom services, was recently launched commercially in Korea. We created a structural model of adoption-diffusion, using the perceived ease-of-use and usefulness of TAM (Technology Acceptance Model) as mediating variables, and a structural model of usediffusion, with the rate of use and the variety of use as mediating variables. To empirically analyze these models, non-users of IPTV were surveyed using the adoptiondiffusion model to identify factors influencing their intention to subscribe to the service. Meanwhile, users of IPTV were surveyed using the use-diffusion model to determine the factors that influence their satisfaction with the service and their intention to re-use it. Under the adoption-diffusion model, we found that trialability, household innovativeness and perceived risk were the determinants of user satisfaction with IPTV, and perceived ease-of-use, the mediating factor. Under the use-diffusion model, complementarity and communication were shown to be the determinants of users' satisfaction with IPTV, and variety of use, the mediating factor. We also found that consumers' intentions to re-use IPTV was strongly influenced by its relative advantages and perceived risks.
\end{abstract}

Keywords: IPTV service, diffusion of innovation, adoption-diffusion, use-diffusion.

Reference to this paper should be made as follows: Motohashi, K.; Lee, D.-R.; Sawng, Y.-W.; Kim, S.-H. 2012. Innovative converged service and its adoption, use and diffusion: a holistic approach to diffusion of innovations, combining adoption-diffusion and use-diffusion paradigms, Journal of Business Economics and Management 13(2): 308-333.

JEL Classification: M15.

\section{Research objective}

The accelerating pace of progress in digital convergence is resulting in an increasing intersection between voice and data communications, and broadcasting and computer technologies, with the broadband network as their point of convergence (Baldwin et al. 
1996). One of the consequences of this rapidly-expanding phenomenon of convergence for users is the changing spectrum of choice in new media. With converged services and devices, offering more than one function, becoming the market norm, the choice for today's consumers is about which product combines features that best suit their various needs and addresses the most complete array of those needs.

IPTV (Internet Protocol TV) is a leading example of this new generation of converged media. IPTV, a superior, interactive alternative to one-way media, like traditional TV services, allows viewers to send and receive voice and data traffic via the television set, connected to the internet. The introduction of IPTV, as a full-triple play solution, pushing the horizon of digital convergence further out, has also had the effect of taking the already intense competition in the TV broadcasting market, pitting digital CATV and digital satellite TV against traditional terrestrial TV, to a new level of complexity.

Meanwhile, the accelerating innovation in the field of convergence technology is triggering active research on the process of diffusion of innovative converged media and devices. As a general rule, the speed of diffusion of an innovative product is influenced both by the characteristics of the new product and the characteristics of consumers (Shih, Venkatesh 2004). Attempts to understand the process of diffusion of new products or new technologies among consumers have been so far made principally in the field of innovation diffusion. Traditional theories on innovation diffusion were focused mainly on adoption. In recent years, however, the focus has been gradually shifting toward the use aspect of innovations.

Existing studies in innovation diffusion draw mostly upon Rogers' (1995) innovationadoption theory and acceptance diffusion models such as the technology acceptance model (TAM). The framework of adoption diffusion, proposed by Rogers, in which the focus is placed on the process of consumers' adoption of new products or services has later become the root of newer theories such as the theory of reasoned action (TRA), the theory of planned behavior (TPB) - a theory expanding on TRA - and the technology acceptance model (TAM) - a modified TRA. Meanwhile, limitations inherent in this adoption-centered approach to the diffusion of innovations have been pointed out by several researchers (Gatignon, Robertson 1985).

Shih and Venkatesh (2004) recently proposed a new innovation diffusion model they baptized "use-diffusion model", as opposed to "adoption-diffusion models". Shih and Venkatesh (2004) argued for the need to shift the focus of diffusion research from 'adoption' to 'use' as a solution to overcome the limitations of traditional approaches in diffusion research while having TAM or other adoption-centered theoretical frameworks. In this alternative approach aimed at moving beyond the adoption-centered paradigm of diffusion, consumers' usage patterns with products or services they are currently using are important predictors for the diffusion process of new products or services. More specifically, how frequently a consumer uses a technology product or service and how varied his/her use of the same product or service may be can explain and determine his / her behavior adopted toward new products or services, and thereby, also the process of their diffusion, according to Shih and Venkatesh (2004). 
Also of note is that in this new model, user categories, segmented by usage patterns, plays a similarly prominent role as the innovation adopter groups in traditional adoption-diffusion models.

In this study, a use-diffusion model was combined with a traditional adoption-diffusion model for a more holistic approach to the diffusion of IPTV services, a representative converged media service. Based on the results of analysis, we derived implications for the marketing of IPTV services that have practical importance for both market entry strategy and the acceleration of diffusion.

\section{Literature review}

\subsection{Characteristics of IPTV services}

The concept of IPTV is far from static and is still evolving. Best known as "IPTV", a name coined in the United States, this application is known in Europe as "ADSL TV" and in Japan as "broadband broadcasting". According to the ITU-T Focus Group, IPTV is a two-way, interactive multimedia data service, coming with a degree of QoS and QoE (Quality of Experience) guarantees, provided through IP-based networks. OVUM, meanwhile, defined IPTV as a service delivering broadcast content and TV programs and videos in the form of VoD, over IP networks. Finally, according to FCC (2005), IPTV is a kind of internet video service for direct downloads of films or TV shows using broadband internet (VoD over the Internet) and advanced TV functions such as DVR (Digital Video Recorder) or PVR (Personal Video Recorder).

When describing IPTV, consumer-perceived characteristics are criteria that are as important as technical characteristics. In technical aspects, one can discern the following four characteristics for IPTV: First, IPTV uses IP (Internet Protocol)-based broadband internet networks as the transmission medium. It is thanks to the use of internet protocol, crucial to enabling broad-ranging communications services, that IPTV can combine voice, data and video services. This is also the key feature that distinguishes IPTV from traditional non-IP network-based TV services such as cable TV and satellite TV, which are limited in the variety of services they can offer due to this very reason. Second, TV is the user interface of IPTV (Kerschbaumer 2000). In Korea, a prototype of IPTV has existed since 1997. This video service, known as "webcasting", is also provided via broadband internet. One crucial difference between webcasting and IPTV, however, is that in the case of the former, the service platform is the computer and not the TV. Third, IPTV provides multi-channel services, enabled by multicasting streaming technology. Webcasting, although it uses broadband internet as transmission means, as does IPTV, is distinct from the latter in that webcasting videos are streamed through unicasting technology and not multicasting technology. Fourth, IPTV enables a wide variety of interactive services such as VoD, TV banking, information search, e-mail and PVR (or DVR). Many next-generation features, such as VoD, T-commerce or T-communication, that set IPTV apart from traditional TV services, are made possible thanks to the twoway communications capability of this IP-based medium (Kim 2004; Kim, C-h 2005).

Meanwhile, there are four main consumer-perceived characteristics of IPTV: multichannel broadcasting, high-definition video, two-way data transfers, and convergence, 
as shown in Table 1 below. Of these four, two-way data transfers may be considered the foremost characteristic of IPTV, insofar as it is a feature offered exclusively by digital media such as digital satellite TV or digital CATV, and not by analog satellite or CATV. Further, not all digital satellite TV services enable two-way data transfers, as this requires broadband return channels as well as real-time interactivity, which can be provided only through bundling with telephone or internet services. Convergence is another characteristic absent in analog CATV services, which, however, is an option available for digital CATV. On the other hand, once fully digitalized Terrestrial TV can provide multi-channel broadcasts and two-way data transfer services. But, for terrestrial TV to enable two-way data transfer, it must also resort to bundling with telecom services, as is the case with digital satellite TV, to gain access to broadband return channels and achieve real-time interactivity. Consumer-perceived performance characteristics of terrestrial TV, upon full digitalization, are, therefore, quite similar to those of digital satellite (Ju, Han 2001; Kim, D-y 2005).

Table 1. Consumer-perceived performance characteristics of IPTV

\begin{tabular}{ll}
\hline \multicolumn{1}{c}{ Characteristics } & \multicolumn{1}{c}{ Description } \\
\hline $\begin{array}{l}\text { Multi-channel } \\
\text { broadcasting }\end{array}$ & Dozens of broadcasting channels \\
\hline High-definition video & High-definition video, Hifi sound, 5.1 or better \\
\hline Two-way data transfer & $\begin{array}{l}\text { Broadband, real-time return channels, for data transfer from } \\
\text { users to the broadcaster. }\end{array}$ \\
\hline Convergence & $\begin{array}{l}\text { Bundled services, other than TV, provided through the set-top box, } \\
\text { home gateway or the platform (TV set), which may vary depending } \\
\text { on the service mix (i.e., double play, triple play or quadruple play). }\end{array}$ \\
\hline
\end{tabular}

\subsection{The innovation adoption-diffusion model and the use-diffusion model}

Research investigating the market acceptance of innovations has long focused on consumers' choice behavior, namely, their resistance to innovation and how continuously they use innovative new products or services once they overcome their initial resistance and adopt them. The central postulate of the adoption-centered approach to the diffusion of innovations is that of the consumers' psychology and their choice behavior in-play in their decision-making purchases that have a determining influence on their final acceptance of a new product or service (Hyori Jeon et al. 2011). For this reason, the object of the inquiry in acceptance-centered studies is to determine what factors influence the choice of information on which individual consumers base their decision to adopt or reject an innovative product or service, and the extent of that influence.

Studies espousing the technology acceptance perspective, further, rest on the following four basic assumptions (Rogers 1983): First, the level of recognition of innovativeness, when an innovative product is released, varies among sellers as well as the marketing scheme they use to distribute the product. Second, early adopters are individuals with definable characteristics and are distinct from late adopters. Third, there exist effective communications channels allowing the interaction between innovation adopters of dif- 
ferent categories (Park, G-s 2004). Fourth, early adopters tend to be opinion leaders and have an influence on the adoption of innovative products or services by others belonging to their social group.

Studies adhering to an adoption-centered approach to diffusion also view the process of adoption as a decision-making process toward adopting or rejecting an innovation, and it consists of a series of psychological phases, including the initial awareness of a new product or service, development of an attitude toward it and the final stage of acceptance/rejection decision-making. The process of acceptance of innovations, insofar as it is the process through which a consumer decides to adopt or reject a new product or service, constitutes the centerpiece of the diffusion of innovations theory. One of the theoretical and methodological consequences of this focus on adoption in diffusion research has largely neglected information processing and behavioral determinants in favor of hierarchy of effects models.

The main limitation of the adoption-centered approach to diffusion, according to Shih and Venkatesh (2004), is the failure to concretely explain the process of diffusion of an innovation as a whole, and in particular, why the speed of diffusion varies and how the personal characteristics of consumers influence this process. As an alternative to the adoption-centered approach, providing a more in-depth understanding of the process of diffusion of innovations, they proposed a new model baptized "use-diffusion model".

One of the key assumptions underlying this model is that consumers' adoption of a converged digital product, at a time when the progress in information technology is rapidly shortening the lifecycle of technologies, can be explained to a great extent by their experience with products they are currently using. Table 2 below provides a summary comparison of the use-diffusion model of Shih and Venkatesh (2004) and the adoption-diffusion model: The first and foremost difference that sets the use-diffusion model apart from the adoption-diffusion model is the usage paradigm. In this model, the consumers' usage pattern with products they currently use, measured in two dimensions, 'rate of use' and 'variety of use', is ascribed predictive capabilities for the diffusion of future technology products and services.

Secondly, in an adoption-diffusion model, the process of diffusion is viewed as a twostage process, consisting of a phase of innovation and a phase of imitation, and this same two-stage conception of diffusion underlies other measures and constructs used in this model, such as the S-shaped diffusion curve, penetration rate and adopter categories. In the use-diffusion model, on the other hand, the focus is on the continuous use of a technology, as well as the degree of technological convergence of a product or service, as perceived with the need for a technology and its influence, and users' adoption behavior vis-a-vis new technologies in general (Kim, Yi 2007).

Thirdly, in adoption-diffusion models, the market is segmented into five categories of innovation adopters, proposed by Rogers (1995), according to the timing of adoption; namely, innovators, early adopters, early majority, late majority and laggards. In the use-diffusion model, meanwhile, the market is segmented according to the type of users and use capabilities, into four user categories: intense users, specialized users, nonspecialized users and limited users. 


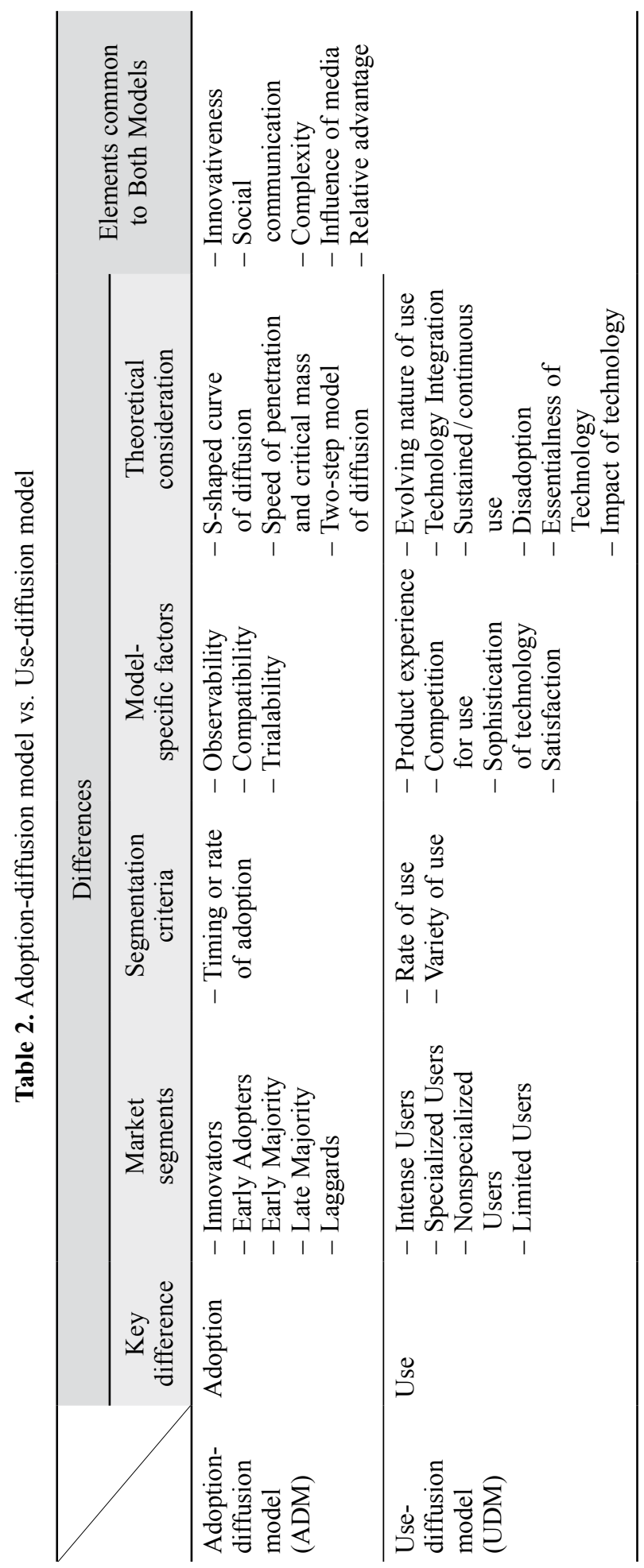


These two models, although they differ in their focus and way of segmenting the market as well as the criteria they use for the segmentation, they also overlap concerning their basic conception of the process of diffusion of innovations (Park, J-m 2005). Concretely, the two models use the same basic variables of influence, such as individual innovativeness, social communication, complexity, media influence and relative advantage. These common variables, however, are not always defined or understood exactly the same way in the two models (Kim, Lee 2005). For example, the innovativeness of a user is a concept distinct from the innovativeness of an adopter. Further, unlike in the adoptiondiffusion model, in which observability, compatibility and trialability constitute the key characteristics of the diffusion process of innovations (Rogers 1995), in the use-diffusion model the same process is explained through product experience, competition for use, sophistication of technology and satisfaction (Shih, Venkatesh 2004).

\section{Empirical research design}

\subsection{Research model}

The objective of this study is to empirically investigate the process of diffusion of converged media services by looking at the case of IPTV. By combining the use-diffusion model proposed by Shih and Venkatesh (2004) with a traditional TAM-based adoptiondiffusion model, we designed a conceptual research model, as shown in Figure 1 below. The research model consists in applying a TAM-based, adoption-diffusion model and the use-diffusion model to IPTV services so as to identify a comprehensive range of factors influencing their diffusion process. The variables selected for the research model are wide-ranging and include major Tam variables, and some of the key variables used in the use-diffusion model by Shih and Venkatesh (2004), the media substitution theory and the total consumer experience (TCE) approach.

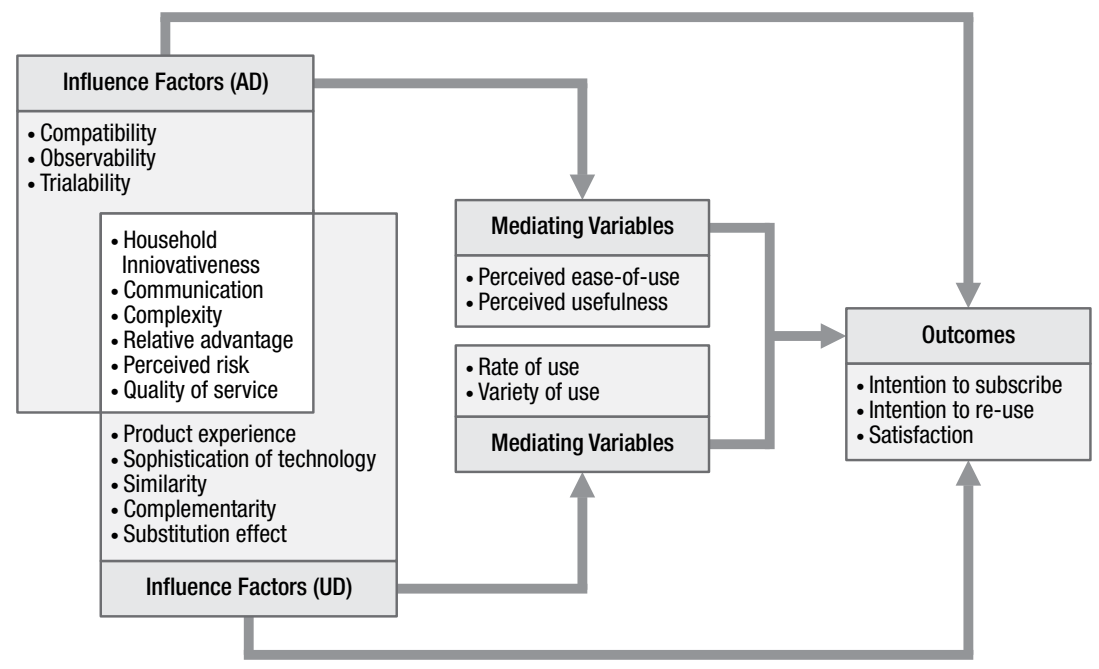

Fig. 1. Research model 
The adoption-diffusion model used in this study is a structural model having perceived ease-of-use and perceived usefulness as mediating variables. For the use-diffusion model, we chose the rate of use and variety of use as mediating variables, following Shih and Venkatesh (2004). The variables used in the latter model include substitution effect and complementarity, constructs in the media substitution theory proposed by $\mathrm{Li}$ (2004). Meanwhile, drawing on Sandström et al. (2008)'s TCE model, we also included product experience among the variables. Satisfaction, intention to re-use, and intention to subscribe were selected as outcome variables for both the acceptance-diffusion and use-diffusion models.

Common factors applicable to both the adoption-diffusion model and the use-diffusion model include household innovativeness, communication, complexity, relative advantage, perceived risk, and service quality. In addition, key TAM factors such as perceived ease-of-use and perceived usefulness, and compatibility, observability and trialability were classified as factors uniquely applying to the adoption-diffusion model. Factors specific to the use-diffusion model include three constructs proposed by Shih and Venkatesh (2004), namely the rate of use, variety of use and sophistication of technology, as well as product experience from the TCE framework, and substitution effect, complementarity and similarity from the media substitution theory as the variable of competition for use.

\subsection{Research hypotheses}

\subsubsection{Hypotheses on the adoption-diffusion of IPTV services}

TAM (Technology Acceptance Model) and other adoption-centered theories argue that the diffusion of an innovation within a social network begins when an individual member comes into the awareness of it and communicates his/her knowledge to others within the network (Chatman 1986).

According to this postulate, for an effective diffusion of a new product, a marketer must promote the product in such a way so as to create as many early adopters as possible, who would, in turn, convert more consumers into adopters through inter-consumer communication. Factors believed to influence consumers' adoption of innovations vary depending on the researcher, even though many share basic premises on the diffusion process, which have been formulated by influential adoption-diffusion theories such as the theory of diffusion of innovations of Rogers (1995), TRA (Theory of Reasoned Action) by Fishbein and Ajzen (1975), TPB (Theory of Planned Behavior) by Ajzen (1991) and TAM (Technology Acceptance Model) by Davis (1989).

Rogers (1995) saw the diffusion of innovations as a progressive process in which the adoption of an innovation, initially only by a small number of people, gradually increases to eventually lead to a mass-market take-up. In other words, Rogers believed that the early phase of innovation adoption was closely linked to the personal innovative tendencies of early users. Cai (2001), drawing on TRA, argued that consumers' attitudes toward innovations and social norms were important determinants of purchase behavior. A consumer's behavioral intention with regard to the adoption of innovative technology, he argues, is directly influenced by his/her personal conviction and evaluation of this 
technology, and social norm-related factors such as trust and conformity. Meanwhile, according to Malhotra et al. (1999), in their study conducted from a TAM perspective, a consumer's attitude toward a new technology product is formed by a combination of social influence factors and perceived technical characteristics of the product, such as its perceived ease-of-use and usefulness.

Among early adoption-diffusion studies, Rogers and Shoemaker (1971) proposed five factors that influence the rate of adoption and diffusion of a new technology product: relative advantage, compatibility, simplicity, observability and trialability. According to Rogers and Sheomaker (1971), the driving factor of the diffusion process is the relative advantage presented by a new technology product over the existing product and the more the innovative product corresponds to consumers' desires, beliefs, values and personal experience, the greater the extent and speed of its diffusion. They further claimed that as the ease-of-use of a new technology facilitates its broad take-up and, in some cases, even trumps price considerations the simpler and more innovative a product, the faster the rate of diffusion. An eye-catching new product, they also maintained, has a better chance of being quickly adopted by the mass-market and odds for market success are greater for products that can be tried in advance of purchase without financial risk to consumers (Kim et al. 2003; Rim et al. 2005).

Robertson and Gatignon (1986), in a study on the adoption of innovative cutting-edge products among industrial buyers, advanced the view that a competitive supplier-side environment influenced the demand-side competition environment thereby also influencing the diffusion of new technology products. Here, the competitive environment has as its key components: industrial competitiveness, company reputation, technology standardization and vertical inter-firm cooperation.

Ram, Jung (1990) stated that the main barrier and resistance factor in consumers' adoption of an innovative product was perceived risk. They argued that when a consumer feels that purchasing a new product carries risk, this perceived risk plays the role of a functional or psychological barrier, producing the effect of delaying the adoption or causing a downright rejection of the same product. In the case of an innovative technology product, the role of perceived risk is mostly that of a functional barrier, they further claimed. In TAM, a dominant paradigm in today's adoption-diffusion research, attitude and behavioral intention-related variables are believed to influence individuals' actual adoption of innovations, through the intermediary of perceived ease-of-use and perceived usefulness (Davis 1989).

Lee et al. (2002) report, in their study on the banking industry's adoption of new technology products, that communication was an important predictor of the actual acceptance of new products. In other words, perceived ease-of-use and perceived usefulness are determinants of consumers' behavioral intentions concerning technology acceptance, and the influence of external variables on technology acceptance is mediated by perceived ease-of-use and usefulness (Agarwal, Karahanna 2000). Lee et al. (2003) validate TAM through their meta-analysis of 101 empirical studies. Joo and Kim (2004), meanwhile, found, in an investigation of technology acceptance in the internet market, 
that innovativeness, external environment and organizational characteristics were the three most important determinants of acceptance.

In this study, we draw on the adoption-diffusion model and related theoretical research, as well as the use-diffusion model by Shih and Venkatesh's (2004), which expands on the latter, and TAM. Factors considered include those unique to the adoption-diffusion model, such as perceived ease-of-use, perceived usefulness, compatibility and accessibility, and those common to both models such as household innovativeness, communication, complexity, relative advantage, perceived risk and service quality. In the adoptiondiffusion model, we set the two key influence factors for technology acceptance in TAM, namely, perceived ease-of-use and perceived usefulness, as mediating variables, and other variables, including compatibility, observability, trialability, household innovativeness, communication, complexity, relative advantage, perceived risk and service quality, as influence factors. Intention to re-use and intention to subscribe and use were considered the adoption outcomes for IPTV, as the former is an existing service and the latter, a service new to the market. Using these variables, we formulated the following hypotheses on the adoption-diffusion of IPTV.

H1: Factors such as compatibility, observability, trialability, household innovativeness, communication, complexity, relative advantage and service quality have a positive influence on the perceived ease-of-use and perceived usefulness of IPTV and the intention to subscribe to IPTV while the perceived risk of IPTV has a negative influence on its perceived ease-of-use, perceived usefulness, and the intention to subscribe to this service.

H2: The perceived ease-of-use and perceived usefulness of IPTV will have positive effects on IPTV subscribers. In other words, if users perceive IPTV to be ea, their purchase potential of IPTV will increase because of the conviction through in advance IPTV service experience.

\subsubsection{Hypotheses on the Use-diffusion of IPTV Services}

Shih and Venkatesh (2004) argued that for a more complete understanding of the process of consumers' acceptance of new products, one needs to move beyond adoption factors and also examine use-diffusion patterns. They developed an alternative model which takes into consideration use-related aspects of innovation diffusion, baptizing it the "use-diffusion model", and successfully tested the model's validity by applying it to the diffusion process of home electronics and technology products. Park J-m (2005), in a study on the diffusion process of cutting-edge technology products, found that product experience was a valid influence factor for the use-diffusion of new technology products and that variety of use effectively influenced the use-diffusion of innovative technologies.

Experiential marketing and TCE (Total Customer Experience) have stressed that product experience influences the use and diffusion of new products. Hahn et al. (1994), for instance, reported that product experience had a direct and determining influence on the conversion of an adopter into a repeater. The basic idea is that as a consumers' experi- 
ence of a new technology increases, they develop a better understanding of its benefits and come to perceive it as an indispensable part of their everyday life. In other words, the more experienced and familiar a consumer is with a technology, the more varied and frequent his/her use of this technology becomes. There have been also studies in technology fields reporting the positive effect of product experience on the use-diffusion of information systems and services.

Cognitiative (1999), for example, reported that users' experiences on the website of an online company not only shapes the users' image of this company, but it also has a decisive influence on their intention to revisit the same website in the future. Huberman et al. (1998) noted that the amount of time spent by users on a website is directly correlated with the value they perceive in the same website. Gillespie et al. (1999) found evidence confirming that users' experience of a website is a major determinant of their loyalty toward the same website. The view that these studies share is that the more relevant a website is to a user, the greater the amount of time he or she spends browsing it. The relevance of a website, in other words, incites users to more thoroughly explore its pages as well as make repeat visits. Bucklin and Sismeiro (2000) reported similar findings indicating that the amount of time spent on a website and number of page views are largely determined by its perceived relevance to users.

As for usage behavior patterns, they are considered important influence factor for product acceptance and diffusion not just within the use-diffusion model by Shih and Venkatesh (2004), but also in many other studies. Kahneman and Lovallo (1988) argued that the greater the capabilities of the individual user to successfully use a new technology product, the stronger the satisfaction they experience with the same product.

In sum, individual users' technology proficiency, as it leads to a higher rate of use as well as a more varied use of a new product, ultimately results in greater satisfaction with the product. Huberman et al. (1998), meanwhile, claimed that the amount of time users spend at a website is directly linked to its value as well as the revenue generated by it. Shih and Venkatesh (2004), pointing out the importance of a household's usage pattern with regard to general technology products as a predictor of their adoption behavior vis-à-vis new technology products, stated that the adoption of an innovative product is largely determined by the extent to which it improves existing products in terms of technological sophistication. Technological sophistication, here, refers to the versatility and capabilities of a technology. The current state of information technology makes it possible for a technology to be sophisticated without being difficult to use. New products with a higher level of technological sophistication, according to Shih and Venkatesh (2004), lead to a higher rate of use and broader, more varied use.

In this study, using the theoretical framework of Shih and Venkatesh (2004) and taking inspirations from the media substitution and TCE theories, we selected the following influence factors for hypotheses related to the use-diffusion of IPTV: product experience, sophistication of technology, similarity, complementarity, substitution effect, household innovativeness, communication, complexity, relative advantage, perceived risk and service quality. Rate of use and variety of use, the two main constructs, related to the usage 
pattern proposed by Shih and Venkatesh (2004), were used as mediating variables. Three outcome variables were selected, namely, satisfaction with IPTV, intention to re-use it and attitude towards subscribing to an IPTV service. Two hypotheses were formulated, as follows, on the relationship between these use-diffusion variables:

H3: Factors, such as the product experience, sophistication of technology, similarity, complementarity, substitution, household innovativeness, communication, complexity, relative advantage, and service quality will have positive effects on the rate of use and the variety of use of IPTV, the satisfaction felt about and intention to re-use IPTV while perceived risk will have negative effects on the rate of use and the variety of use of the IPTV product as well as the satisfaction felt about and intention to re-use IPTV.

H4: The rate of use and diversity of the IPTV product will have positive effects on the satisfaction felt about and intention to re-use IPTV.

\subsection{Measurement}

This study considers variables that are common to the adoption-diffusion model and the use-diffusion model and those that are specific to each of them. Variables specific to the adoption-diffusion model considered in this study include compatibility, trialability, observability, perceived ease-of-use and perceived usefulness.

Compatibility refers to the extent to which a new product corresponds to the desire, trust, values and the past experience of a consumer (Rogers 1995). In this study, we measured compatibility through the compatibility of a product to the current purchase behavior, cultural background and the lifestyle of a consumer (Jang, Cho 2000). As for observability, this variable was measured through the observability of benefits resulting from the use of a product, overall usefulness of the product and information communication (Jang, Cho 2000). Trialability was measured through the limited period of use, capabilities to use the functions of a product, ability to use the product when needed and performance enhancement resulting from the use of the product (Alexandra 2007). Perceived usefulness was measured through the ability to quickly access information useful to a user, usefulness of a product for conducting purchases and the variety of information made accessible through the product (Davis 1989). Perceived ease-of-use was measured through the ease of using desired functions and convenient methods for accessing the internet and other manipulations (Davis 1989; Venkatesh 2000).

Variables specific to the use-diffusion model that are included in this study are product experience, technological sophistication, similarity, complementarity, substitution effect, and the rate and variety of use.

We measured product experience through the length of use of a product, from the initial purchase of the product to the current point in time (Noyes, Garland 2006). In this study, adopting the perspective of TCE, we measured emotional experience-related factors, such as pleasures derived from IPTV, the experience of smooth integration of functionalities and overall usefulness (Sandström 2008). Specifically, we measured the experience of using the five main functions of IPTV (VoD, personalized features, two- 
way communication, value-added services, entertainment and media content), which may be translated into pleasure, smooth functional integration, temporal flexibility, increased convenience for everyday activities and general usefulness. Technological sophistication, meanwhile, was measured through the versatility and capabilities of the product/service (Shih, Venkatesh 2004). As for functional similarity, we took into account the extent to which a consumer, based on his/her personal experience, perceives a product/service as functionally similar to existing ones (Martin, Stewart 2001). Complementarity, which describes the relationship between two products/services that simultaneously benefit by helping the other maximize its usefulness, was measured with regard to the ability to increase the existing media's entertainment potential and usefulness for information access and as a communication tool (Jeffrey, Atkin 1996). Substitution effect, corresponding to the relationship between two products/services in which the use of one dispenses the use of the other - in other words, one replaces the other - was measured with regard to TV, internet, mobile phone, DMB (Digital Multimedia Broadcasting) and other existing media in terms of IPTV's potential to substitute their functionalities, the content they provide and the time spent using this media (Li 2004). Variety of use was measured by the variety of content types for which a product/service is used as the means of access (Ram, Jung 1990). The uses considered in this study range from communication with family members, family entertainment, care and support of family members, home shopping, education and information (Tinnell 1985). Rate or frequency of use was measured by number of hours spent using a product/service (Shin, Venkatesh 2004).

Variables common to the adoption-diffusion model and use-diffusion model included in this study are household innovativeness, communication, complexity, relative advantage, perceived risk and service quality.

Household innovativeness refers to how willing a household is to adopt an innovation (Gatignon, Robertson 1985) or, in other words, how rapid a household adopts an innovation, and this was measured by curiosity/creativity, risk preference, voluntary simplicity, creative re-use, and multiple use potential (Price, Ridgway 1983). Communication was measured by whether there are helpers to provide assistance with regard to the use of a product/service, the possibility to acquire knowledge needed for its use, and how large or complete the related information source is (Venkatesh 2000). Items used to measure complexity were difficulty of use, complexity of manipulation, understanding of advanced functions, and the need for explanations on advanced functions (Rogers 1983). Relative advantage was measured by the comparative price advantage of a product/service, the ease and speed of manipulation, and portability (Moore, Benbasat 1991). Perceived risk was measured through performance risk, financial risk, social risk, and psychological risk (Hirunyawipada, Paswan 2006). Quality of service was measured by the accuracy, relevance, completeness and comprehensiveness of information provided through a product/service, and the variety of information made accessible by it (Parasuraman et al. 1985).

The outcome variables chosen for this study were satisfaction, intention to re-use, and intention to subscribe. Items used to measure satisfaction were positive feelings and overall 
satisfaction with a product/service, and favorable quality assessment (Shih, Venkatesh 2004; Kim, Y-j 2005). Intention to re-use was measured by the intention to continue to use the current product/service and the intention to recommend it to others (Hellier et al. 2003). Finally, the intention to subscribe/use by applying to IPTV was measured by the intention to subscribe to an IPTV service, as indicated by households. Households were provided with a basic description of IPTV and were asked to decide whether they would subscribe to the service, within a short period of time (Eastlick 1993).

\subsection{Gathering and sampling of data}

The data were gathered from both users and non-users of IPTV, in accordance with the objectives of the study. The data from non-user households were used in the analysis of the IPTV adoption-diffusion model while the data from user households were used in the analysis of the IPTV use-diffusion model.

The data were collected through a face-to-face interview conducted at the homes or workplaces of the respondents, using two different questionnaires for households currently using an IPTV service and those that were not. The respondents were selected among households residing in four major Korean cities, namely, Seoul, Incheon, Busan and Daegu. 500 total copies of the adoption-diffusion analysis survey questionnaire were distributed to households that are not currently using IPTV, which broke down by region to 200 copies to Seoul-based households and 100 copies each in Incheon, Busan and Daegu-based households; 414 valid responses were returned. As for the usediffusion analysis questionnaire designed for households that are currently using IPTV, 250 copies were distributed - 100 copies in Seoul and 50 copies each in Busan, Incheon and Daegu - and 160 valid responses were returned. The survey was conducted over a period of one month, between October 15, 2008 and November 14, 2008.

As for the geographical distribution of respondents who returned valid responses, Seoul accounted for $44.2 \%$ of the total households that are currently not using IPTV (183 out of 414 total households that returned a valid response) followed by Busan ( 85 households), Daegu and Incheon (73 households for both cities). As for households that are currently using IPTV, 90 of them resided in Seoul, corresponding to $56.3 \%$ of total households that returned a valid response, while 29 others resided in Busan, 23 in Daegu and 18 in Incheon (Appendix).

\section{Results}

To test the reliability and validity of the variables used in the two diffusion models, we calculated Cronbach's $\alpha$ and performed a factor analysis. The results suggest that all variables had a sufficient level of reliability and validity. Those of the constructs used in the adoption-diffusion model that proved to have an acceptable level of validity through the factor analysis were, then, tested for internal consistency reliability. Cronbach's $\alpha$ was 0.660 or greater for all factors tested. The internal consistency reliability analysis, performed on the constructs used in the use-diffusion model, resulted in a Cronbach's $\alpha$ of 0.8 or greater for all of the factors. 


\subsection{The adoption-diffusion model}

We performed a structural analysis of the adoption-diffusion models predicting the diffusion of IPTV, using AMOS v.70. The resulting goodness-of-fit measures are provided in Table 3 below, listing the values separately for IPTV:

The goodness of fit of the overall model proved to be highly adequate.

The structural analysis of the adoption-diffusion model on IPTV was based on TAM. The results of the structural analysis of the adoption-diffusion models on IPTV are listed in Table 3 below.

The results reveal that, trialability, perceived risk, quality of service, household innovativeness and perceived ease-of-use had a direct influence on potential users' intention to subscribe to IPTV. Also, these variables had indirect mediation effects through its perceived ease-of-use. What this implies in practical terms is that in order to promote the adoption-diffusion of IPTV, marketers must try to enhance consumer-perceived easeof-use of this application. Thus, hypotheses 1 and 2 on the adoption-diffusion model on IPTV are generally well supported.

\subsection{The use-diffusion model}

To test hypotheses 3 and 4 on the use-adoption of IPTV, we performed a structural analysis of the use-adoption model using the survey response data collected from IPTV users. The goodness-of-fit measures obtained from the analysis are provided in Table 4 below.

Goodness-of-fit values from all indices, from $\chi^{2}$ to GFI, AGFI, RMR and NFI, were within a very satisfactory range. The goodness-of-fit of the use-adoption model on IPTV was, notably, superior to that of the two adoption-diffusion models on IPTV, respectively, analyzed earlier. Based strictly on the goodness-of-fit values, the use-diffusion model on IPTV may be considered to possess more explanatory power than the two other models for the diffusion process in real-world settings.

The results of structural analysis revealed that complementarity, a construct specific to the use-diffusion model, and communication, a construct common to the adoptiondiffusion and use-diffusion models, had a direct influence on the rate of use of IPTV and the satisfaction felt by users. The intention to re-use IPTV, meanwhile, was influenced by perceived risk and relative advantage. This is an indication that in order to enhance consumers' satisfaction with IPTV, in the context of promoting the use and diffusion of this service, providers must look to increase its complementarity vis-à-vis existing media and strengthen its communication-related functions. Meanwhile, to incite current users to re-subscribe to IPTV, providers need to adopt a strategy which reduces perceived risk associated with this service while simultaneously increasing its relative advantage. Specifically, the rate of use of IPTV was directly influenced by variables from the media substitution theory, such as complementarity and the substitution effect, and communication. The variety of use was likewise positively influenced by the media substitution variables such as similarity and complementarity, and the sophistication of technology. 
Table 3. Structural analysis of use-diffusion model on IPTV

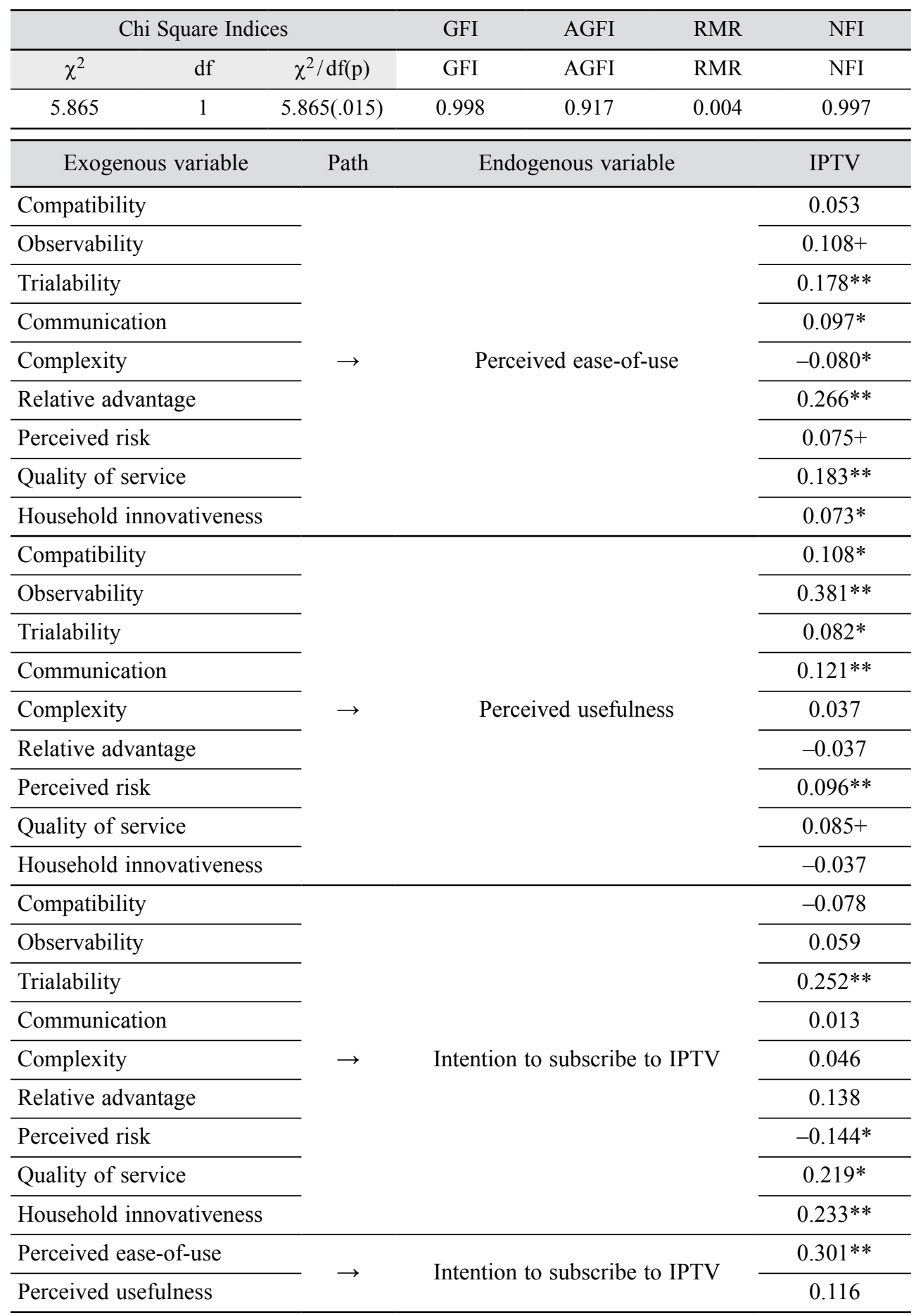

Notes: $+\mathrm{p}<.1 ; * \mathrm{p}<.05 ; * * \mathrm{p}<.01$ 
These results imply that media substitution variables constitute important determinants for the rate of use and the variety of use of innovative products like converged media services. Also, satisfaction with IPTV was positively influenced by complementarity, the substitution effect and communication - variables which proved to also influence the rate of use. In the meantime, the intention to re-use IPTV was positively influenced by complexity and relative advantage, but negatively influenced by perceived risk. However, the study found that the rate of use and the variety of use of IPTV did not significantly influence consumers' intentions to re-use this service. Hypotheses 3 and 4 on use-diffusion of IPTV were, therefore, partially supported.

Table 4. Results of structural analysis of the use-diffusion model on IPTV

\begin{tabular}{|c|c|c|c|c|c|c|c|}
\hline$\chi^{2}$ & $\mathrm{df}$ & $\chi^{2} / \mathrm{df}$ & $\mathrm{GH}$ & AGF & & RMR & NFI \\
\hline 1.822 & 1 & 1.822 & 0.9 & 0.918 & & 0.0008 & 0.998 \\
\hline $\begin{array}{l}\text { Exogenous } \\
\text { variable }\end{array}$ & Path & $\begin{array}{l}\text { Endogenous } \\
\text { variable }\end{array}$ & Estimate & $\begin{array}{l}\text { Exogenous } \\
\text { variables }\end{array}$ & Path & $\begin{array}{c}\text { Endogenous } \\
\text { variable }\end{array}$ & Estimate \\
\hline $\begin{array}{l}\text { Product expe- } \\
\text { rience }\end{array}$ & & & 0.088 & $\begin{array}{l}\text { Product ex- } \\
\text { perience }\end{array}$ & & & 0.005 \\
\hline $\begin{array}{l}\text { Sophistica- } \\
\text { tion of tech- } \\
\text { nology }\end{array}$ & & & 0.060 & $\begin{array}{l}\text { Sophistica- } \\
\text { tion of tech- } \\
\text { nology }\end{array}$ & & & 0.060 \\
\hline Similarity & & & -0.020 & Similarity & & & -0.020 \\
\hline $\begin{array}{l}\text { Complemen- } \\
\text { tarity }\end{array}$ & & & $0.362 * *$ & $\begin{array}{l}\text { Complemen- } \\
\text { tarity }\end{array}$ & & & $0.362 * *$ \\
\hline $\begin{array}{l}\text { Substitution } \\
\text { effect }\end{array}$ & & & $0.191^{*}$ & $\begin{array}{l}\text { Substitution } \\
\text { effect }\end{array}$ & & & $0.191^{*}$ \\
\hline $\begin{array}{l}\text { Household in- } \\
\text { novativeness }\end{array}$ & $\rightarrow$ & Rate of use & -0.125 & $\begin{array}{l}\text { Household } \\
\text { innovative- } \\
\text { ness }\end{array}$ & $\rightarrow$ & Satisfaction & -0.125 \\
\hline $\begin{array}{l}\text { Communica- } \\
\text { tion }\end{array}$ & & & $0.260 * *$ & $\begin{array}{l}\text { Communica- } \\
\text { tion }\end{array}$ & & & $0.260 * *$ \\
\hline Complexity & & & 0.051 & Complexity & & & 0.051 \\
\hline $\begin{array}{l}\text { Relative ad- } \\
\text { vantage }\end{array}$ & & & $0.197+$ & $\begin{array}{l}\text { Relative ad- } \\
\text { vantage }\end{array}$ & & & $0.197+$ \\
\hline Perceived risk & & & 0.015 & $\begin{array}{l}\text { Perceived } \\
\text { risk }\end{array}$ & & & -0.135 \\
\hline \multirow[t]{3}{*}{$\begin{array}{l}\text { Service qual- } \\
\text { ity }\end{array}$} & & & 0.104 & $\begin{array}{l}\text { Service } \\
\text { quality }\end{array}$ & & & 0.144 \\
\hline & & & & Rate of use & \multirow[b]{2}{*}{$\rightarrow$} & \multirow[b]{2}{*}{ Satisfaction } & 0.045 \\
\hline & & & & $\begin{array}{l}\text { Variety of } \\
\text { use }\end{array}$ & & & $0.301 * *$ \\
\hline
\end{tabular}


End of Table 4

\begin{tabular}{|c|c|c|c|c|c|c|c|}
\hline $\begin{array}{l}\text { Exogenous } \\
\text { variable }\end{array}$ & Path & $\begin{array}{c}\text { Endogenous } \\
\text { variable }\end{array}$ & Estimate & $\begin{array}{l}\text { Exogenous } \\
\text { variables }\end{array}$ & Path & $\begin{array}{c}\text { Endogenous } \\
\text { variable }\end{array}$ & Estimate \\
\hline $\begin{array}{l}\text { Product expe- } \\
\text { rience }\end{array}$ & & & 0.107 & $\begin{array}{l}\text { Product } \\
\text { experience }\end{array}$ & & & 0.133 \\
\hline $\begin{array}{l}\text { Sophistica- } \\
\text { tion of tech- } \\
\text { nology }\end{array}$ & & & $0.169^{*}$ & $\begin{array}{l}\text { Sophistica- } \\
\text { tion of tech- } \\
\text { nology }\end{array}$ & & & 0.169 \\
\hline Similarity & & & $0.451 * *$ & Similarity & & & -0.059 \\
\hline $\begin{array}{l}\text { Complemen- } \\
\text { tarity }\end{array}$ & & & -0.008 & $\begin{array}{l}\text { Complemen- } \\
\text { tarity }\end{array}$ & & & 0.084 \\
\hline $\begin{array}{l}\text { Substitution } \\
\text { effect }\end{array}$ & & & $0.329 * *$ & $\begin{array}{l}\text { Substitution } \\
\text { effect }\end{array}$ & & & 0.098 \\
\hline $\begin{array}{l}\text { Household in- } \\
\text { novativeness }\end{array}$ & $\rightarrow$ & $\begin{array}{l}\text { Variety } \\
\text { of use }\end{array}$ & -0.100 & $\begin{array}{l}\text { Household } \\
\text { innovative- } \\
\text { ness }\end{array}$ & $\rightarrow$ & $\begin{array}{l}\text { Intention } \\
\text { to re-use }\end{array}$ & -0.081 \\
\hline $\begin{array}{l}\text { Communica- } \\
\text { tion }\end{array}$ & & & -0.116 & $\begin{array}{l}\text { Communica- } \\
\text { tion }\end{array}$ & & & 0.035 \\
\hline Complexity & & & 0.135 & Complexity & & & $0.178^{*}$ \\
\hline $\begin{array}{l}\text { Relative ad- } \\
\text { vantage }\end{array}$ & & & 0.144 & $\begin{array}{l}\text { Relative ad- } \\
\text { vantage }\end{array}$ & & & $0.288 * *$ \\
\hline Perceived risk & & & 0.007 & $\begin{array}{l}\text { Perceived } \\
\text { risk }\end{array}$ & & & $-0.300 * *$ \\
\hline \multirow[t]{3}{*}{$\begin{array}{l}\text { Service qual- } \\
\text { ity }\end{array}$} & & & -0.069 & $\begin{array}{l}\text { Service } \\
\text { quality }\end{array}$ & & & -0.050 \\
\hline & & & & Rate of use & \multirow[b]{2}{*}{$\rightarrow$} & \multirow{2}{*}{$\begin{array}{l}\text { Intention } \\
\text { to re-use }\end{array}$} & 0.102 \\
\hline & & & & $\begin{array}{l}\text { Variety of } \\
\text { use }\end{array}$ & & & 0.122 \\
\hline
\end{tabular}

Notes: $+\mathrm{p}<.1 ; * \mathrm{p}<.05 ; * * \mathrm{p}<.01$

\section{Conclusions}

\subsection{Recapitulation of results}

The results of the analysis of factors influencing the diffusion of IPTV services, using the adoption-diffusion model and the use-diffusion model, are summarized in Table 5.

First, in the case of the adoption-diffusion model, measuring non-users' intentions to adopt IPTV, the trialability and perceived ease-of-use proved to be determinants effectively influencing the adoption behavior of potential subscribers, among endogenous factors, specific to this approach. Among common factors, we found that household innovativeness, perceived risk, and service quality were determinants of adoption of IPTV. 
Table 5. Summary of results

\begin{tabular}{|c|c|c|c|c|}
\hline & \multirow{2}{*}{ Variables } & \multirow{2}{*}{$\begin{array}{c}\text { Adoption-diffusion } \\
\text { (Non-users) }\end{array}$} & \multicolumn{2}{|c|}{ Use-diffusion (Users) } \\
\hline & & & Satisfaction & $\begin{array}{l}\text { Intention to } \\
\text { re-use }\end{array}$ \\
\hline \multirow{12}{*}{$\begin{array}{l}\text { Model- } \\
\text { specific } \\
\text { factors }\end{array}$} & Compatibility & & & \\
\hline & Observability & & & \\
\hline & Trialability & $* *$ & & \\
\hline & Perceived ease-of-use & $* *$ & & \\
\hline & Perceived usefulness & & & \\
\hline & Product experience & & & \\
\hline & $\begin{array}{l}\text { Sophistication of } \\
\text { technology }\end{array}$ & & & \\
\hline & Similarity & & & \\
\hline & Complementarity & & $* *$ & \\
\hline & Substitution effect & & $*$ & \\
\hline & Rate of use & & & \\
\hline & Variety of use & & $* *$ & \\
\hline \multirow{6}{*}{$\begin{array}{l}\text { Common } \\
\text { factors }\end{array}$} & $\begin{array}{l}\text { Household } \\
\text { Innovativeness }\end{array}$ & $* *$ & & \\
\hline & Communication & & $* *$ & \\
\hline & Complexity & & & $*$ \\
\hline & Relative advantage & & + & $* *$ \\
\hline & Perceived risk & $* *$ & & $* *$ \\
\hline & Service quality & * & & \\
\hline
\end{tabular}

Notes: +Moderate influence; *Strong influence; **Very strong influence

Our results also indicate that for innovative, converged media services like IPTV, perceived ease-of-use is an important mediator of the relationship between factors influencing adoption-use behavior and actual adoption-use. What this finding suggests in practical terms is that enhancing ease-of-use is crucial to promote the adoption-diffusion of IPTV. Our results also show that in order to enhance the perceived ease-of-use of IPTV, service providers must emphasize observability, trialability, communication, relative advantage, and service quality, at the level of the product and technology, and try to capitalize on household innovativeness at the level of consumers.

Second, the use-diffusion model on IPTV proved to have high explanatory power for the diffusion process of converged media services. Our analysis, based on the results of a survey of consumers currently subscribed to an IPTV service, found that the use- 
diffusion model far exceeded the adoption-diffusion model in terms of explanatory power with regard to satisfaction felt with the service and the intention to re-use the service. The use-diffusion model also received very high goodness-of-fit scores from all indices. The satisfaction that consumers experience with IPTV was influenced by complementarity, the substitution effect and the variety of use, among endogenous factors specific to the use-diffusion model, and communication and relative advantage, among common factors.

The intention to re-use IPTV was significantly influenced by factors common to the two diffusion models, such as complexity, relative advantage and perceived risk, rather than factors uniquely associated with the use-diffusion model. These results indicate that in order to enhance users' satisfaction with IPTV and, thereby, incite them to continuously use the service, service providers must increase both its complementarity and substitution effect vis-à-vis existing media and induce more varied use of it. Consumers' intention to re-use IPTV, as we have said earlier, is more greatly influenced by factors common to the two diffusion models, namely, relative advantage and perceived risk, rather than those that are specific to the use-diffusion model.

\subsection{Implications}

As a holistic approach to understanding the diffusion process of IPTV, a converged media service that is rapidly rising as an alternative to CATV, the traditional TV service with the highest household penetration, this study empirically analyzed both an adoption-diffusion model of innovation and a use-diffusion model. The main theoretical and practical implications of this study are as follows:

At a theoretical level, this study is significant in four ways: First, it is an empirical evaluation of the use-diffusion model proposed by Shih and Venkatesh (2004) that compares it to a traditional adoption-diffusion model. Although there have been some attempts, in recent years, to explain the use-diffusion model, as an alternative to the adoptiondiffusion model, these attempts fall short of establishing whether and to what degree the former exceeds the latter in terms of explanatory power. The findings of this study provide concrete evidence that the use-diffusion model surpasses the adoption-diffusion model in its ability to explain the diffusion of innovations in real-world situations.

Second, this study proposed a set of adoption factors and use factors to consider from the adoption-diffusion perspective and use-diffusion perspective, which influence the prospect and process of diffusion for IPTV. In identifying adoption factors for IPTV, this study distinguished common factors from model-specific factors, thereby providing a theoretical basis for designing a strategic marketing framework.

Third, this study found evidence that the rate and variety of use, the two key mediators in the use-diffusion model by Shih and Venkatesh (2004), do not have as determining or conclusive an influence on the diffusion outcome as perceived ease-of-use or perceived usefulness with constructs used in TAM, a model based on the traditional adoptiondiffusion paradigm. Shih and Venkatesh (2004), who focused on different use patterns displayed by users of innovative technology products or services, divided the market 
into user segments, derived factors influencing the use-diffusion of new products and services from the use patterns of these user segments, and accordingly predicted the outcome of diffusion. Our results, however, revealed that usage patterns based on rate of use and variety of use, alone, cannot adequately explain the use-diffusion of innovations.

Fourth, our study found that product experience and technological sophistication, two constructs proposed by Shih and Venkatesh (2004) as important influence factors for the diffusion of a new product, had no significant influence or predictive power on the diffusion outcome. Product experience, being a central concept in experiential marketing and the TCE paradigm, provides an ample, theoretical basis justifying its importance as a variable in the diffusion process of new products or services. We found, however, that concerning IPTV and, by extension, converged digital media in general, product experience and technological sophistication determine less satisfaction felt by consumers and their intention to re-use the service than what is contributed to the process in which traditional influence factors such as relative advantage or perceived risk influence the intention to newly subscribe to the service or continuously use it. In sum, the experience of an innovative product or its technological sophistication alone proved to be insufficient to explain its diffusion process or outcome. Our results, therefore, suggest that product experience and technological sophistication, rather than being independent predictors of the use-diffusion process of innovations, are links mediating the influence of other factors.

This study offer a number of practical implications for the marketing of IPTV, now set to begin commercial service in Korea, concerning both market entry and market penetration strategies. When designing a market entry and marketing strategy for IPTV, service providers must try to create a positive perception among its potential users, especially with regard to its trialability and ease-of-use. Customer relationship management is to be perceived as significant approach impacting the success of business company in the long run (Korsakiene 2009). Our results, furthermore, suggest that service providers need a strategy to reduce the opportunity costs arising from the adoption of IPTV as well as the learning curve required before consumers become proficient with its use. Meanwhile, to solidify the grip on the early adopter market, the marketing strategy must stress IPTV's complementarity vis-à-vis other media and its substitution effect, so as to enhance satisfaction among this adopter segment and, thereby, magnify the word- ofmouth, marketing effect.

The two-way, interactive data transfer capability of IPTV must be also emphasized so as to increase consumers' awareness of this medium as a communications solution and not just as a media delivery service. Underlining the fact that IPTV provides customized content is also a valid market entry strategy. Finally, in order to prevent the desertion of IPTV by early adopters, for instance, at the end of a promotional, free trial period, providers must emphasize the relative advantage of this service to incite them to continue to use it. Our findings also point to the need to reduce perceived risk associated with subscribing to an IPTV service. 


\section{References}

Agarwal, R.; Karahanna, E. 2000. Time flies when you're having fun: cognitive absorption and beliefs about information technology usage, MIS Quarterly 24(4): 665-694.

http://dx.doi.org/10.2307/3250951

Ajzen, I. 1991. The theory of planned behavior, Organizational Behavior and Human Decision Processes 50: 179-211. http://dx.doi.org/10.1016/0749-5978(91)90020-T

Alexandra, M. 2007. Social Acceptance of Renewable Energy Innovations: the Role of Technology Cooperation in Urban Mexico. Development studies Institute (DESTIN), London School of Economics and Political Science (LSE), London, UK.

Baldwin, T. F.; McVoy, D. S.; Steinfield, C. 1996. Convergence: Integrating Media, Information and Communication. Thousand Oaks and London: Sage Publications.

Bucklin, R. E.; Sismeiro, C. 2000. A model of web site browsing behavior estimated on clickstream data, Journal of Marketing Research August: 249-267.

Cai, X. 2001. A Test of the Functional Equivalence Principle in the New Media Environment: Unpublished Doctoral Dissertation. Indiana University, Indiana.

Chatman, E. A. 1986. Diffusion theory: a review and test of a conceptual model in information diffusion, Journal of American Society for Information Science 37: 377-386.

Cognitiative, R. 1999. E-commerce and the evolution of retail shopping behaviour, Pulse of the Customer 1(2): 1-16; 67-89.

Davis, F. D. 1989. Perceived usefulness, perceived ease of use, and user acceptance of information technology, MIS Quarterly 13(3): 319-340. http://dx.doi.org/10.2307/249008

Eastlick, M. A. 1993. Predictors of videotex adoption, Journal of Direct Marketing 7(3): 66-74. http://dx.doi.org/10.1002/dir.4000070309

FCC. 2005. IPTV and FCC regulations, 11st Annual Report. Available from Internet: www.fcc.org Fishbein, M.; Ajzen, I. 1975. Belief, Attitude, Intention and Behavior: an Introduction to Theory and Research. Addisio-Wesley, Reading, MA.

Gatignon, H. A.; Robertson, T. S. 1985. A propositional inventory for new diffusion research, Journal of Consumer Research 11(March): 849-867. http://dx.doi.org/10.1086/209021

Gillespie, A.; Krishna, M.; Oliver, C.; Olsen, K.; Thiel, M. 1999. Online Behavior: Stickiness. Available from Internet: http://elab.vanderbilt.dedu/research

Hahn, M. H.; Park, S. H.; Krishnamurthi, L.; Zoltners, A. A. 1994. Analysis of new product diffusion using a four-segment trial-repeat model, Marketing Science 13(3): 224-247.

http://dx.doi.org/10.1287/mksc.13.3.224

Hellier, P. K.; Carr, G. M.; Richard, J. A. 2003. Customer repurchase intention: a general structural equation model, European Journal of Marketing 37: 1762-1800.

http://dx.doi.org/10.1108/03090560310495456

Hirunyawipada, T.; Paswan, A. K. 2006. Consumer innovativeness and perceived risk: implications for high technology product adoption, Journal of Consumer Marketing 23(4): 182-198. http://dx.doi.org/10.1108/07363760610674310

Huberman, B. A.; Pirolli, P. L. T.; Piktow, J. E.; Lukose, R. M. 1998. Strong regularities in world wide web surfing, Science 280(3): 95-97. http://dx.doi.org/10.1126/science.280.5360.95

Hyori Jeon; Yonghee Shin; Munkee Choi; Jae Jeung Rho; Myung Seuk Kim. 2011. User adoption model under service competitive market structure for next-generation media services, ETRI Journal 33(1): 110-120. http://dx.doi.org/10.4218/etrij.11.0110.0160

Jang, Dae-ryeon; Cho, Seong-do. 2002. A study on users of high-tech products on resistance against innovation within organizations, and control effects of perceived self-capability, Korean Society of Consumer Studies 13(3): 245-262. 
Jeffrey, L.; Atkin, D. 1996. Predicting use of technologies for consumer and communication needs, Journal of Broadcasting \& Electronic Media 40: 318-330.

http://dx.doi.org/10.1080/08838159609364356

Joo, Y.; Kim, Y. 2004. Determinants of corporate adoption of e-Marketplace: an innovation theory perspective, Journal of Purchasing \& Supply Management 10: 89-101.

http://dx.doi.org/10.1016/j.pursup.2004.01.001

Ju, Yeong-hyeok; Han, Sang-man. 2001. A Study of behavioral characteristics of profitable customers' visit to websites: centering on comparison of models of revenue, Marketing Research 16(2): 69-91.

Kahneman, D.; Lovallo, D. 1988. Timid choices and bold forecasts: a cognitive perspective on risk and risk taking, Management Science 39: 17-33. http://dx.doi.org/10.1287/mnsc.39.1.17 Kerschbaumer, K. 2000. AOLTV Could Jump-start IPTV, Broadcasting and Cable. New York.

Kim, Byeong-seon. 2004. Reevaluation of media substitution in home space: centering on comparison of the use of Web and TV watching, Korea Press Journal 48(2): 57-78.

Kim, Chang-hwan. 2005. Broadband TV Service Trends. IT Report, Korea Electronics Technology Institute. Available from Internet: www.eic.re.kr

Kim, Do-yeon. 2005. Influential factors and policy arguments regarding the introduction of IPTV, Research on Broadcasting (summer issue): 117-138.

Kim, Gyeong-gyu; Yi, Jeong-u; Kim, Hye-seon. 2003. Reliability and risk on the behavior of adopting internet banking, Business Administration Research 32(6): 1771-1797.

Kim, Jin-woo; Lee, In-sung. 2005. Use contexts for the mobile internet: a longitudinal study monitoring actual use of mobile internet services, Korean Business Information Journal 18(3): 269-292.

Kim, Mun-tae; Yi, Jong-ho. 2007. Innovativeness of N-generation consumers influencing usediffusion and Re-adoption of convergence products, and the influence of reference group's conformity, Industrial Economics Research 20(3): 1253-1278.

Kim, Yu-jeong. 2005. A study on the participation in, use of, and satisfaction over cyber communities, Korea Press Journal 49(3): 291-318.

Korsakiene, R. 2009. The innovative approach to relationships with customers, Journal of Business Economics and Management 10(1): 53-60. http://dx.doi.org/10.3846/1611-1699.2009.10.53-60 Lee, E. J.; Lee, J. K.; David, W. S. 2002. The influence of communication source and mode on consumer adoption of technological innovation, Journal of Consumer Affairs 36(1): 1-27. http://dx.doi.org/10.1111/j.1745-6606.2002.tb00418.x

Lee, E. J.; Lee, J. K.; David, W. S. 2003. A two-step estimation of consumer adoption of technology-based service innovations, Journal of Consumer Affairs 37(2): 256-278. http://dx.doi. org/10.1111/j.1745-6606.2003.tb00453.x

Li, Shu-Chu Sarrina. 2004. Exploring the factors influencing the adoption of interactive cable television services in Taiwan, Journal of Broadcasting and Electronic Media 48(3): 466-483. http://dx.doi.org/10.1207/s15506878jobem4803_7

Malhotra, Y.; Dennis, F.; Galletta, A. 1999. Extending the technology acceptance model to account for social influence: theoretical bases and empirical validation, in Proceeding of the 32nd Hawaii International Conference on System Sciences, 6-14.

Martin, I. M.; Stewart, D. W. 2001. The differential impact of goal congruency on attitudes, intentions, and the transfer of brand equity, Journal of Marketing Research 38: 471-484.

http://dx.doi.org/10.1509/jmkr.38.4.471.18912

Moore, G. C.; Benbasat, I. 1991. Development of an instrument to measure the perceptions of adopting an information technology behavior, Information Systems Research 2(3): 192-222. http://dx.doi.org/10.1287/isre.2.3.192 
Noyes, J. M.; Garland, K. J. 2006. Comment on evaluating cognitive demand, Perceptual and Motor Skills 102(1): 118-120. http://dx.doi.org/10.2466/pms.102.1.118-120

Parasuraman, A. V.; Zeithaml, A.; Berry, L. L. 1985. A conceptual model of service quality and its implications for future research, Journal of Marketing 49: 41-50.

http://dx.doi.org/10.2307/1251430

Park, Gwang-sun. 2004. A Study on the characteristics of early adopters in digital satellite broadcasting services, Korea Press Journal 48(1): 84-111.

Park, Jae-moon. 2005. An Empirical Study on the Use-Diffusion and Adoption of InnovationCentering on Consumer Experiences in Major High-Tech Products: a Doctoral Paper on Business Administration, Graduate School of Dong-Eui University.

Price, L. L.; Ridgway, N. M. 1983. Development of a scale to measure use innovativeness, $A d$ vances in consumer Research 10: 679-684.

Ram, S.; Jung, H. S. 1990. The conceptualization and measurement of product usage, Journal of the Academy of Marketing Science 18(1): 67-76. http://dx.doi.org/10.1007/BF02729763

Rim, Myung-Hwan; Cho, Sang-Sup; Moon, Choon-Geol. 2005. Measuring economic externalities of IT and R \& D, ETRI Journal 27(2): 206-218.

Robertson, T. S.; Gatignon, H. 1986. Competitive effects on technology diffusion, Journal of Marketing July: 1-12. http://dx.doi.org/10.2307/1251581

Rogers, E. M. 1983. Diffusion of Innovation. Third edition. New York: Free Press.

Rogers, E. M. 1995. Diffusion of Innovation. Forth edition. New York: Free Press.

Rogers, E. M.; Shoemaker, F. F. 1971. The Diffusion of Innovations. New York, NY: Free Press.

Sandström, S.; Edvardsson, B.; Kristensson, P.; Magnusson, P. 2008. Value in use through service experience, Managing Service Quality 18(2): 112-126.

http://dx.doi.org/10.1108/09604520810859184

Shih, C. F.; Venkatesh, A. 2004. Beyond adoption: development and application of a use-diffusion model, Journal of Marketing 68: 59-72. http://dx.doi.org/10.1509/jmkg.68.1.59.24029

Tinnell, C. S. 1985. An ethnographic look at personal computers in the family setting, Marriage and Family Review 8(1-2): 59-69. http://dx.doi.org/10.1300/J002v08n01_05

Venkatesh, V. 2000. Determinants of perceived ease of use: integrating control, intrinsic ease of use: integrating control, intrinsic motivation, and emotion into the technology acceptance model, Information System Research 11(4): 342-365. http://dx.doi.org/10.1287/isre.11.4.342.11872

\section{APPENDIX}

\section{Survey Results}

Surveyed Household Locations

\begin{tabular}{lcccc}
\hline \multirow{2}{*}{ Region } & \multicolumn{2}{c}{ IPTV Non-user } & \multicolumn{2}{c}{ IPTV User } \\
\cline { 2 - 5 } & Frequency & Ratio (\%) & Frequency & Ratio (\%) \\
\hline Seoul & 183 & $44.2 \%$ & 90 & $56.3 \%$ \\
\hline Inchoen & 85 & $20.5 \%$ & 29 & $18.1 \%$ \\
\hline Busan & 73 & $17.6 \%$ & 23 & $14.4 \%$ \\
\hline Daegu & 73 & $17.6 \%$ & 18 & $11.3 \%$ \\
\hline Total & 414 & $100 \%$ & 160 & $100 \%$ \\
\hline
\end{tabular}


End of Appendix

Respondent characteristics

\begin{tabular}{|c|c|c|c|c|c|}
\hline \multirow{2}{*}{ Variables } & \multirow{2}{*}{ Category } & \multicolumn{2}{|c|}{$\begin{array}{l}\text { Adoption-diffusion } \\
\text { (IPTV Non-user) }\end{array}$} & \multicolumn{2}{|c|}{$\begin{array}{l}\text { Use-diffusion } \\
\text { (IPTV User) }\end{array}$} \\
\hline & & $\begin{array}{l}\text { Frequency } \\
\text { (persons) }\end{array}$ & Ratio (\%) & $\begin{array}{l}\text { Frequency } \\
\text { (persons) }\end{array}$ & Ratio (\%) \\
\hline \multirow{2}{*}{ Sex } & Male & 187 & 45.2 & 90 & 56.3 \\
\hline & Female & 227 & 54.8 & 70 & 43.8 \\
\hline \multirow{4}{*}{ Age } & Age 20-29 & 62 & 15.0 & 42 & 26.3 \\
\hline & Age 30-39 & 126 & 30.4 & 83 & 51.9 \\
\hline & Age $40-49$ & 157 & 37.9 & 27 & 16.9 \\
\hline & Age over 50 & 69 & 16.7 & 8 & 5.0 \\
\hline \multirow{2}{*}{$\begin{array}{l}\text { Marital } \\
\text { Status }\end{array}$} & Married & 352 & 85.0 & 87 & 54.4 \\
\hline & Single & 62 & 15.0 & 73 & 45.6 \\
\hline \multirow{5}{*}{ Education } & $\begin{array}{l}\text { Under middle school } \\
\text { graduate }\end{array}$ & 3 & 0.7 & 19 & 11.9 \\
\hline & High school graduate & 214 & 51.7 & 11 & 6.9 \\
\hline & In college & 10 & 2.4 & 113 & 70.6 \\
\hline & College graduate & 183 & 44.2 & 17 & 10.6 \\
\hline & $\begin{array}{l}\text { Master's degree } \\
\text { or higher }\end{array}$ & 4 & 1.0 & 160 & 100.0 \\
\hline \multirow{11}{*}{ Job } & Self-employed & 92 & 22.2 & 23 & 14.4 \\
\hline & Sales & 61 & 14.7 & 6 & 3.8 \\
\hline & Production & 16 & 3.9 & 2 & 1.3 \\
\hline & Office Worker & 109 & 26.3 & 76 & 47.5 \\
\hline & Technician & 44 & 10.6 & 13 & 8.1 \\
\hline & Management & 15 & 3.6 & 3 & 1.9 \\
\hline & Specialized Job & 15 & 3.6 & 17 & 10.6 \\
\hline & House maker & 55 & 13.3 & 8 & 5.0 \\
\hline & Student & 6 & 1.4 & 6 & 3.8 \\
\hline & Unemployed & 1 & 0.2 & 5 & 3.1 \\
\hline & Other & 0 & 0 & 1 & 0.6 \\
\hline \multirow{4}{*}{$\begin{array}{l}\text { Average } \\
\text { income }\end{array}$} & $\begin{array}{l}\text { Under KRW } \\
2.5 \text { million }\end{array}$ & 70 & 16.9 & 28 & 17.5 \\
\hline & KRW 2.5-5 million & 277 & 66.9 & 76 & 47.5 \\
\hline & KWR 5-7.5 million & 54 & 13.0 & 37 & 23.1 \\
\hline & $\begin{array}{l}\text { Above KRW } \\
7.5 \text { million }\end{array}$ & 13 & 3.1 & 19 & 11.9 \\
\hline Total & & 414 & 100.0 & 160 & 100.0 \\
\hline
\end{tabular}


Kazuyuki MOTOHASHI is a professor in the Department of Technology Management for Innovation, at the University of Tokyo's Graduate School of Engineering in Japan. Until early 2011, he had held various positions at the Ministry of Economy, Trade and Industry of the Japanese Government, and was an economist at the OECD and an associate professor at Hitotsubashi University. His research interest covers a broad range of issues in economic and statistical analysis of innovation, including the economic impacts of information technology, the international comparison of productivity, the national innovation system focusing on science and industry linkages and SME innovation, and entrepreneurship policy. He has published several papers and books on the above issues. Mr. Motohashi was awarded a Master of Engineering degree from the University of Tokyo, an MBA from Cornell University and a PhD in business and commerce from Keio University. URL: http://www.mo.t.u-tokyo.ac.jp/.

Deog-Ro LEE (Ph.D., Yonsei University, Seoul, Korea) is a professor at Seowon University's Business School in Korea. His current interests in the field include creativity, leadership, humor, and labormanagement partnership. He has written 26 professional books including 6 translation books and 4 book chapters, and has published numerous articles in academic and professional journals such as the Journal of Organizational Behavior, Personnel Review, Creativity Research Journal, Korean Management Review, and the Korean Journal of Sociology.

Yeong-Wha SAWNG is a director of the Technology Foresight Research Team at the Electronics and Telecommunications Research Institute (ETRI) in Korea. He received an MIM in Business Management from Whitworth University in the USA and a PhD in Technology Management from Hanyang University in Seoul, Korea in 1995 and 2006, respectively. He joined ETRI in 2000, and has been working in the areas of digital convergence, IT policy, mobile application, technology management, and business strategy. His research interests also include high-tech. marketing, technology management strategy, the e/m-Biz model, and consumer behavior. He has been published in several international and Korean journals. Since 2008, he has been working on a second PhD (Dissertation PhD in Technology Management for Innovation) at the University of Tokyo in Japan.

Seung-Ho KIM is a professor in the School of Health Service Management at Kyungwoon University in Gumi City, Korea. He received his MS degree in Business Administration at Seoul National University in Korea in 1998. Before he joined as a faculty member of Kyungwoon University, he had been with KINE as a vice president and a professor of Daegu Hanny University. His main interests include technology innovation, technology convergence and the evolution of industrial ecology, strategic management of technology, and the $R \& D$ project management. 